\title{
Current Perspectives on Spinal Cord Stimulation for the Treatment of Cancer Pain
}

This article was published in the following Dove Press journal:

Journal of Pain Research

\author{
Jonathan $M$ Hagedorn (D) \\ Thomas P Pittelkow (D) \\ Christine L Hunt \\ Ryan S D'Souza \\ Tim J Lamer (iD
}

Department of Anesthesiology and Perioperative Medicine, Division of Pain Medicine, Mayo Clinic, Rochester, MN, USA
Correspondence: Tim J Lamer Department of Anesthesiology and Perioperative Medicine, Division of Pain Medicine, Mayo Clinic, Rochester, MN 55905, USA

$\mathrm{Tel}+\mathrm{I}-507-284-25$ I I

Email Lamer.Tim@mayo.edu

\begin{abstract}
Cancer and cancer treatment-related chronic pain affect a significant number of patients. The etiology of this pain is diverse and may include nociceptive and/or neuropathic characteristics. Treatment is often multifactorial and may require advanced interventional techniques, such as spinal cord stimulation (SCS). This narrative review provides a thorough overview of cancer-related pain mechanisms and the use of SCS for cancer-related pain. Additionally, a review of the precautions that should be considered when caring for this patient population is provided with recommendations for safe care when utilizing these techniques.
\end{abstract}

Keywords: spinal cord stimulation, cancer pain, neuromodulation, radiation, chemotherapy, surgery

\section{Introduction}

Cancer-related pain is one of the most debilitating and feared symptoms, afflicting approximately nine million cancer patients annually. ${ }^{1}$ The etiology of pain in this population is unique and may be related to primary or metastatic disease in twothirds of patients, whereas other causes including surgery, chemotherapy, radiation, immobility, osteoporosis, and infection may lead to pain in a third of patients. ${ }^{2}$ Pain may be aggravated by mood disorder, fatigue, cachexia, nausea, and other symptoms that commonly manifest in cancer patients. ${ }^{2}$ It is concerning that conventional pharmacologic therapy based on the World Health Organization (WHO) guidelines may fail to achieve acceptable pain relief in $10-15 \%$ of cancer patients. ${ }^{3,4}$ Furthermore, chronic cancer pain may have a significant neuropathic pain component in up to $40 \%$ of patients, which often responds poorly to conventional pharmacologic therapy including opioid-based therapy. ${ }^{5}$

In patients with refractory pain, interventional pain management modalities may provide substantial pain relief. Interventional approaches include common local anesthetic and steroid injections, neuraxial analgesia (intrathecal or epidural catheter), and sympathetic blockade from neurolytic injection and radiofrequency ablation. ${ }^{6}$ More recently, the use of spinal cord stimulation (SCS) and other neuromodulation approaches have been proposed and studied as an indication for cancer-related pain. SCS involves delivery of electric fields between metal electrodes in the epidural space which modulates pain signaling in the spinal cord. The mechanisms by which SCS relieves or modulates pain have been studied extensively. The electrical signals from the SCS electrodes are thought to exert painrelieving effects by one or more of several mechanisms: increased levels of several 
dorsal horn neurotransmitters known to modulate pain including serotonin, norepinephrine, gamma-aminobutyric acid, and acetylcholine; suppression or modulation of hyperexcitable or sensitized dorsal horn wide dynamic range neurons that are implicated in many neuropathic pain states; antidromic stimulation of peripheral nerve fibers leading to the peripheral release of vasodilatory neurotransmitters including calcitonin gene-related peptide and nitric oxide; and supraspinal effects. The mechanism of action for dorsal root ganglion (DRG) stimulation appears to be a direct action on abnormally firing primary cell bodies in the DRG. These putative mechanisms are all congruent with the observed clinical pain-relieving effects of SCS and DRG stimulation. ${ }^{7-9}$

While our understanding of the underlying mechanisms of analgesia in SCS continues to evolve, studies have established the efficacy of SCS in many non-malignant pain syndromes including failed back surgery syndrome, angina, limb ischemia, painful diabetic peripheral neuropathy, and complex regional pain syndrome. ${ }^{8-12}$ However, the efficacy of SCS in cancer-related pain remains understudied and warrants future investigations.

This facet of SCS research is clinically important because inadequately treated cancer pain may have a negative impact on quality of life, which in turn may also exacerbate the severity of pain. ${ }^{13-15}$ Untreated pain may lead to unwillingness to comply with treatment plans, leading to therapeutic failure and influencing survival from cancer progression. ${ }^{16}$ Higher indirect hospital costs may result from unnecessary hospital admissions, emergency department visits, and need for psychological treatment. ${ }^{17}$ Some studies have reported that the severity of cancerrelated pain is associated with shorter survival, independent of known prognostic factors. ${ }^{18,19}$ While the evidence is mixed, studies also suggest that there may be an association with long-term opioid use and shorter survival in cancer patients, warranting consideration of non-opioid-based therapy and interventional management. ${ }^{20}$ Recently, SCS has been shown to reduce systemic analgesic and opioid use in patients with intractable chronic pain. ${ }^{21}$

Despite an increasing number of recent clinical trials evaluating the efficacy of SCS for cancer pain, there have been few efforts to systematically synthesize the impact of SCS on analgesic efficacy, patient satisfaction, safety, and opioid consumption in cancer-related pain. In this narrative review, we provide evidence for the use of SCS for the treatment of cancer-related pain, important considerations when planning neuromodulation therapy in this patient population, and areas for future investigation.

\section{Methods}

This is a narrative review of the literature regarding the use of SCS in the treatment of cancer pain. The objective was to review the literature to gain an understanding of the potential benefits of SCS therapy in cancer-related pain syndromes. A librarian-assisted literature search of the PubMed, Science Direct, and Google Scholar databases was utilized. The terms "spinal cord stimulation," "cancer pain," "oncology," and "neuromodulation" were searched and potential manuscripts collected. Results were limited to publications in English and a date range was not used. This resulted in finding 127 articles. Additionally, the literature search was supplemented by review of former systematic and narrative reviews. Manuscripts were excluded if they were meta-analyses, reviews, or study rationales, or if they were not related to the desired subject matter. Studies regarding anesthesia during surgery were also excluded. After abstract and full manuscript review, a total of 17 articles were included in this review.

\section{Review of Cancer-Related Pain and SCS}

There are significant challenges associated with cancerrelated pain diagnosis and treatment given the heterogeneous nature of pain presentation and the individual experience. The focus of this discussion will review the use of spinal cord stimulation for the treatment of chronic cancer pain syndromes as it relates to tumor-related pain syndromes affecting the nociceptive (somatic and visceral) and neuropathic aspects of cancer-related pain.

Greater than $75 \%$ of cancer patients suffer chronic pain related to the direct effects of their malignancy. ${ }^{22}$ When treating pain, it is helpful to try to identify the source of pain as that typically allows for a more targeted therapeutic intervention. Unfortunately, a significant proportion of cancer patients continue to suffer from under-treated pain symptoms, which has driven much research into the use of SCS as a treatment option for the nociceptive and neuropathic pain syndromes. The primary drivers for somatic nociceptive pain arise from primary osseous lesions, as well as secondary bone metastases and multifocal bone metastases including the axial and appendicular skeletal systems. The pain often associated with bony involvement may be due to numerous factors, including direct cortical invasion of the tumor, pathologic fracture of a weight-bearing segment or long bone, or 
inflammation and distortion of the neurobiological milieu of the primary and surrounding tissues, as is often seen in hematologic malignancies. ${ }^{23,24}$ As pain is often an early symptom prior to functional loss or neurologic impairment, it is paramount to identify these underlying concerning lesions and offer symptomatic treatment. ${ }^{25}$ Although no studies to date have specifically evaluated the use of SCS for the treatment of refractory somatic cancer-related bone pain, there have been case reports and case series noting significant improvements in the patients' reported pain outcomes (Table 1). Mirpuri et al discussed a single female with hereditary osteochondromas who failed conventional medical management and was successfully treated with SCS. ${ }^{26}$ This case demonstrated the important early research into multifactorial bone pain and the potential for opioid reduction and improvement in activities of daily living. Hutson et al reported a case series focused on different forms of interventional therapies for sacroiliac tumors. The authors reported that SCS resulted in improved pain scores, physical performance, and opioid cessation for the patient that received SCS as a definitive therapy. ${ }^{27}$ Although SCS is most often used for neuropathic pain syndromes, growing reports such as this describe its role in targeting of dorsal column pathways that are implicated in nociceptive pain syndromes.

Table I Publications Discussing the Use of Spinal Cord Stimulation for Cancer-Related Chronic Pain

\begin{tabular}{|c|c|c|c|c|c|c|}
\hline $\begin{array}{l}\text { Author, } \\
\text { Year }\end{array}$ & $\begin{array}{l}\text { Type of } \\
\text { Study }\end{array}$ & $\begin{array}{l}\text { Total } \\
\text { No. of } \\
\text { Patients }\end{array}$ & Cancer Type & Pain Etiology & $\begin{array}{l}\text { Stimulation } \\
\text { Mode }\end{array}$ & Results \\
\hline $\begin{array}{l}\text { Meglio, } \\
1989^{36}\end{array}$ & $\begin{array}{l}\text { Retrospective } \\
\text { Review }\end{array}$ & 11 & Unspecified & "Cancer pain" & $\begin{array}{l}\text { Traditional } \\
\text { SCS }\end{array}$ & $\begin{array}{l}3 \text { out of II patients were } \\
\text { implanted with permanent device } \\
\text { after successful trial. Of those } 3 \text {, } \\
\text { one lost efficacy }<30 \text { days after } \\
\text { implant. The other two reported } \\
>50 \% \text { pain relief until death at } 2.5 \\
\text { and } 5 \text { months post-implant. }\end{array}$ \\
\hline $\begin{array}{l}\text { Shimoji, } \\
1993^{37}\end{array}$ & $\begin{array}{l}\text { Retrospective } \\
\text { Review }\end{array}$ & 52 & Unspecified & $\begin{array}{l}\text { "Carcinoma/sarcoma" } \\
\text { pain of the head/face (I), } \\
\text { neck/upper extremities } \\
\text { (3), trunk (43), and lower } \\
\text { extremities (5) }\end{array}$ & $\begin{array}{l}\text { Traditional } \\
\text { SCS }\end{array}$ & $\begin{array}{l}\text { Patients reporting }>50 \% \text { pain } \\
\text { relief at unspecified time period: } \\
\text { Head/face - I/I } \\
\text { Neck/upper extremities - } 2 / 3 \\
\text { Trunk - } 40 / 43 \\
\text { Lower extremities - } 2 / 5 \\
\text { Authors did note that cancer } \\
\text { pain patients had an } 80 \% \text { pain } \\
\text { relief initially and } 20 \% \text { pain relief } \\
\text { at I year. The number of patients } \\
\text { at each time period is not } \\
\text { reported. }\end{array}$ \\
\hline $\begin{array}{l}\text { Eisenberg, } \\
2002^{35}\end{array}$ & Case Report & 1 & $\begin{array}{l}\text { Foramen-magnum } \\
\text { meningioma }\end{array}$ & $\begin{array}{l}\text { Central neurogenic pain } \\
\text { related to } \mathrm{Cl} \text { lesion }\end{array}$ & $\begin{array}{l}\text { Traditional } \\
\text { SCS }\end{array}$ & $\begin{array}{l}\text { Near complete pain relief } 9 \\
\text { months post-implant }\end{array}$ \\
\hline $\begin{array}{l}\text { Yakovlev, } \\
2008^{4}\end{array}$ & Case Report & 1 & $\begin{array}{l}\text { Anal squamous cell } \\
\text { carcinoma }\end{array}$ & $\begin{array}{l}\text { Inguinal adenopathy- } \\
\text { related pain from } \\
\text { metastasis }\end{array}$ & $\begin{array}{l}\text { Traditional } \\
\text { SCS }\end{array}$ & $\begin{array}{l}75-90 \% \text { improvement in pain and } \\
\text { functional status at } 12 \text { months } \\
\text { post-implant }\end{array}$ \\
\hline $\begin{array}{l}\text { Mirpuri, } \\
2015^{26}\end{array}$ & Case Report & I & $\begin{array}{l}\text { Hereditary } \\
\text { Multiple } \\
\text { Osteochondromas } \\
\text { (HMO) }\end{array}$ & $\begin{array}{l}\text { Pelvis and lower } \\
\text { extremity skeletal pain } \\
\text { from HMO }\end{array}$ & $\begin{array}{l}\text { Traditional } \\
\text { SCS }\end{array}$ & $\begin{array}{l}30 \% \text { reduction in pain at } 6 \\
\text { months post-implant }\end{array}$ \\
\hline $\begin{array}{l}\text { Hutson, } \\
2017^{27}\end{array}$ & Case Report & I & Breast cancer & $\begin{array}{l}\text { Sacral skeletal pain from } \\
\text { metastasis }\end{array}$ & $\begin{array}{l}\text { Traditional } \\
\text { SCS }\end{array}$ & $\begin{array}{l}\text { Weaned off all opioids and } \\
\text { ambulating without pain } 3 \\
\text { months after implant }\end{array}$ \\
\hline
\end{tabular}

Abbreviations: SCS, spinal cord stimulation; VAS, visual analog scale. 
Viscerosomatic pain syndromes present another challenging subset of cancer-related pain. Pain of this nature is often seen in patients with chronic abdominopelvic pain from neoplasm-related injury to the peritoneal organs, soft tissue invasion from thoracic and pleural malignancies, and even dysmotility of hollow viscus organs which is common in patients with gastrointestinal or gynecologic malignancies. Typical provocation of visceral pain results in a dull, boring, non-focal and non-specific pain. Given the neurophysiologic convergence of nociceptive afferent input with classic neuropathic fibers, specifically the sympathetic and parasympathetic nervous system, the primary intent of an intervention is to target the various sympathetic nervous system ganglia with secondary intention to disrupt the nociceptive transmission of pain. It is important to understand that visceral sensory afferents are primarily thinly myelinated $\mathrm{A} \delta$ and unmyelinated $\mathrm{C}$-fibers, which can become highly sensitized thus leading to altered nociceptive processing. The mechanistic rationale for targeting the central convergence pathway with dorsal column stimulation stems from basic science research that has demonstrated reduction of centrally amplified highly sensitized neuronal tissue through neuroelectrophysiologic changes that occur in the spinal cord and supraspinal neurologic centers. ${ }^{28-31}$ As with somatic-related cancer pain syndromes, the use of SCS for viscerally mediated cancer pain has not been formally evaluated. A number of case reports have suggested successful use of SCS for treatment of refractory viscerally mediated cancer-related pain with improvements in pain scores, functional performance, and opioid reduction. ${ }^{30-32}$ Clearly, the communication between the somatic and neuropathic systems is more integrally related than is commonly appreciated and much of the soundest research available stems from the well-established role SCS plays in treatment of neuropathic pain.

Tumor-related neuropathic pain syndromes most often are caused by direct tumor invasion of the peripheral nerves, plexuses, nerve roots and central nervous system. The simple act of neural compression, destruction, or inflammation may lead to the typical neuropathic pain symptoms including paroxysmal aching or sharp sensations, burning or electrical dysesthetic pain, and may or may not be associated with functional or motor changes. The location and presentation of symptoms depend on the neural structure being affected. Focal mononeuropathies may be more isolated to a peripheral nerve distribution, whereas a polyneuropathy or plexopathy may present with more diffuse circumferential or patchy pain. Spinal cord injury often presents with a burning dysesthetic pain in the area localized to the injury or the long tracts leading to appendicular symptoms. Given the diverse nature of cancer-related neuropathic pain, it presents many challenges to successful treatment and remains largely refractory to conservative medical management and pharmacologic treatment. The use of SCS for the treatment of cancer-related neuropathic pain is of great interest. Dating back nearly half a century to the first SCS device in the late 1960s, the use of SCS to change the nociceptive spinothalamic signaling pathway has shown promising results. ${ }^{33}$ Numerous case reports and series have demonstrated an improvement in pain intensity, reduced opioid consumption, and improvement in daily performance for various cancer-related neuropathic pain syndromes including low back pain, lower extremity peripheral neuropathy, and spinal cord injury. $40,31,34-40$ Despite the lack of a randomized control trial leading to the suggestion that current evidence is insufficient for the role of SCS in the cancer pain population, the most recent systematic review found that over $80 \%$ of patients reported at least $50 \%$ reduction of pain and decreased use of opioid medications. ${ }^{41}$ This simply summarizes the need to develop future research to assess the efficacy of SCS for the treatment of cancer-related pain in a prospective fashion.

While the literature supporting the use of SCS for the treatment of cancer-related somatic and neuropathic pain continues to mature, the treatment of individuals with refractory cancer-related pain remains paramount. Although the exact mechanism is not completely understood, one must recognize that the use of SCS likely targets central and supraspinal centers through multiple different unique actions including mediation of wide dynamic range neurons, the complex inter-neuronal glial network, and alterations in the pain pathway neurotransmitters. ${ }^{42,43} \mathrm{By}$ targeting the nociceptive fibers in the dorsal horn and spinothalamic pathways with electrical energy, one may reduce the excitability seen with tumor-related somatic and neuropathic cancer pain syndromes leading to improved pain intensity, reduced opioid consumption, and improved physical performance.

\section{Review of Cancer Treatment-Related Pain and SCS}

Treatment of cancer including surgery, radiation, and chemotherapy can result in a number of pain syndromes. Pain due to cancer treatment contributes to more than $70 \%$ of patients who report cancer-associated pain, including $40 \%$ 
of patients reporting neuropathic pain. ${ }^{44}$ Pain following cancer treatment can be categorized as neuropathic or nociceptive, with or without predominant features of central sensitization. ${ }^{45}$ Pain that is disproportionate to the underlying injury or pathology, does not follow logical anatomical distribution, and is characterized by hypersensitivity or allodynia, may represent the development of central sensitization following cancer treatment. Pain related to cancer treatment may be refractory to pharmacologic agents and more conservative interventions, and in such cases neuromodulation may be considered. ${ }^{38,39}$

Chemotherapy can result in a number of acute and chronic pain syndromes in cancer patients. ${ }^{46}$ Almost $75 \%$ of patients with cancer who have pain have neuropathic or nociceptive symptoms directly related to their cancer, but chronic pain is known to occur as a result of cancer treatment as well, sometimes months or even years after therapy. Pain related to hormonal therapies can manifest as arthralgias, dyspareunia, gynecomastia, myalgias, and osteoporotic compression fractures. Pain due to radiation may result in chest wall pain, cystitis, osteoporotic fractures, painful secondary malignancies, myelopathy, painful plexopathies, and peripheral mononeuropathies. ${ }^{46}$ Symptoms may be localized to the area of treatment or be more generalized in the case of some secondary malignancies. Radiation myelopathy can present with symptoms similar to spinal cord injury including neuropathic pain as well as other sensory and/or motor symptoms. Peripheral neuropathy is a well-known complication of chemotherapy but other pain syndromes can result including avascular necrosis, vertebral compression fractures, and carpal tunnel syndrome. Bony complications can result from longterm corticosteroid use and are often painful. Examples of pain following cancer surgery include painful lymphedema, residual limb pain following amputation (including phantom limb pain), and pelvic floor pain after gynecologic surgery, as well as surgical site pain from laparotomy, mastectomy, radical neck dissection, or thoracotomy. Pain related to cancer treatment can manifest in many different syndromes at multiple time points. Awareness of this type of cancer-associated pain is important for understanding its relationship to the patient's disease process, whether its distribution is logical or expected, and whether it may be expected to put a patient at risk for central sensitization.

A number of case reports and case series report successful treatment of chemotherapy-associated neuropathic pain (Table 2). ${ }^{34,47}$ Cata et al described the successful utilization of SCS in two patients with severe neuropathic pain of the lower limbs following systemic chemotherapy refractory to medications including opioid and anti-seizure medications. ${ }^{34}$ The authors carefully assessed neuropathic pain symptom burden incorporating the use of quantitative sensory testing prior to SCS trial in order to ascertain the degree of neuropathic pain. Abd-Elsayed et al reported successful treatment of chemotherapy-associated neuropathic pain in the setting of breast cancer with SCS. ${ }^{47}$ Ting et al described the use of SCS to treat cisplatininduced Raynaud's syndrome resulting in bilateral progressive upper extremity digital ischemia requiring distal phalangeal amputation. The patient experienced significant improvement in pain symptoms as well as ulcer healing. ${ }^{48}$

Radiation therapy can result in a number of iatrogenic nerve injuries including plexopathies, myelopathy, and peripheral mononeuropathies. Elahi et al described the successful treatment of pudendal entrapment neuropathy following pelvic radiation therapy in a patient with stage IV prostate cancer utilizing dorsal column SCS. ${ }^{49}$ Hamid et al utilized surgically placed dorsal column SCS for treatment of bilateral lower extremity pain in the setting of transverse myelitis developing after radiation therapy for non-small cell lung carcinoma. ${ }^{50}$ Painful complications of radiation therapy can result in particularly intractable symptoms in many patients, and it is important to recognize symptoms of central or peripheral nerve pain that might be expected to manifest in patients treated with radiation therapy.

Chronic pain following surgical treatment for cancer can result in nociceptive or neuropathic pain; however, the literature consists mainly of reports of neuromodulation being used to treat primarily neuropathic pain only. Goyal et al described the successful utilization of peripheral field stimulation for post-thoracotomy scar pain. ${ }^{51}$ The patient initially had a robustly positive response to intercostal nerve block using anesthetic although benefits were shortlived. Wininger et al treated post-thoracotomy pain in a patient treated for non-small cell lung cancer using SCS, with the patient reporting $75 \%$ relief 2 years following implant. ${ }^{52}$ Neuromodulation is commonly applied in post-amputation phantom limb pain, and Viswanathan et al describe a series of four patients with phantom limb pain following lower limb amputation of cancerous tumors. All four patients experienced at least $80 \%$ pain relief, although one developed an allergic reaction to the IPG and the other a surgical site infection following routine exchange of the IPG. ${ }^{53}$ Dorsal column SCS has been employed to treat lower extremity neuropathic pain developing after T5 
Table 2 Publications Discussing the Use of Spinal Cord Stimulation for Cancer Treatment-Related Chronic Pain

\begin{tabular}{|c|c|c|c|c|c|c|}
\hline $\begin{array}{l}\text { Author, } \\
\text { Year }\end{array}$ & Study Type & $\begin{array}{l}\text { No. of } \\
\text { Patients }\end{array}$ & Cancer Type & Pain Etiology & $\begin{array}{l}\text { Stimulation } \\
\text { Mode }\end{array}$ & Results \\
\hline Cata, $2004^{34}$ & Case series & 2 & $\begin{array}{l}\text { Pt.\#I: Melanoma } \\
\text { (elbow); Pt.\#2: } \\
\text { Ewing sarcoma }\end{array}$ & $\begin{array}{l}\text { Chemotherapy-induced painful } \\
\text { neuropathy }\end{array}$ & & $\begin{array}{l}\text { Pt.\#I: } 55 \% \text { pain relief and } 80 \% \\
\text { reduction in OME at } 4 \text { months } \\
\text { Pt.\#2: } 35 \% \text { pain relief and I3\% } \\
\text { reduction in OME at } 3 \text { months }\end{array}$ \\
\hline Ting, $2007^{48}$ & Case report & 1 & $\begin{array}{l}\text { Metastatic } \\
\text { pancreatic cancer } \\
\text { with metastases to } \\
\text { lung and liver }\end{array}$ & $\begin{array}{l}\text { Chemotherapy-induced Raynaud's } \\
\text { syndrome }\end{array}$ & & $\begin{array}{l}>50 \% \text { pain relief during three day trial } \\
\text { period, good pain control at I-month } \\
\text { post-implant with NRS }<4\end{array}$ \\
\hline $\begin{array}{l}\text { Hamid, } \\
2007^{50}\end{array}$ & Case report & 1 & $\begin{array}{l}\text { Non-small cell lung } \\
\text { carcinoma }\end{array}$ & $\begin{array}{l}\text { Neuropathic pain with radiation- } \\
\text { induced transverse myelitis }\end{array}$ & & $\begin{array}{l}\text { NRS } 0-1 / 10 \text { from baseline } 9-10 / 10 \\
\text { severity at } 18 \text { months post-implant }\end{array}$ \\
\hline $\begin{array}{l}\text { Yakovlev, } \\
2008^{4}\end{array}$ & Case Report & 1 & $\begin{array}{l}\text { Metastatic epidural } \\
\text { tumor from colon } \\
\text { carcinoma }\end{array}$ & $\begin{array}{l}\text { Radiation induced low back and } \\
\text { right lower extremity pain }\end{array}$ & $\begin{array}{l}\text { Traditional } \\
\text { SCS }\end{array}$ & $\begin{array}{l}90-100 \% \text { improvement in pain, } \\
\text { stopped all opioids, improved } \\
\text { functioning and sleep at } 12 \text { month } \\
\text { post-implant }\end{array}$ \\
\hline Lee, $2009^{54}$ & Case report & 1 & Spinal meningioma & $\begin{array}{l}\text { Post-surgical neuropathic pain after } \\
\text { spinal meningioma removal }\end{array}$ & & $\begin{array}{l}\text { After } 8 \text { months post-implant, VAS } \\
\text { score in right calf/sole was I (from } 9 \\
\text { pre-trial), VAS score in upper back/ } \\
\text { right flank was } 4 \text { (from } 9 \text { pre-trial); } \\
\text { functional status and effectiveness of } \\
\text { SCS as evaluated by ODI, SF-MPQ, } \\
\text { and BDI were all improved from (pre- } \\
\text { operatively to post-operatively) } 58 \% \\
\text { to } 30 \% \text {, from score } 40 \text { to } 20 \text {, and } \\
\text { from score } 7 \text { to } 0 \text {, respectively }\end{array}$ \\
\hline $\begin{array}{l}\text { Yakovlev, } \\
2010^{39}\end{array}$ & $\begin{array}{l}\text { Retrospective } \\
\text { Review }\end{array}$ & 14 & Lung cancer & $\begin{array}{l}\text { All patients had undergone } \\
\text { thoracotomy, lung resection, and } \\
\text { postoperative radiation. There was } \\
\text { no evidence of local recurrence or } \\
\text { metastasis. Presumed to be } \\
\text { treatment related. }\end{array}$ & $\begin{array}{l}\text { Traditional } \\
\text { SCS }\end{array}$ & $\begin{array}{l}\text { At } 12 \text { months post-implant, all } \\
\text { patients had }>50 \% \text { VAS pain } \\
\text { reduction. All patients decreased or } \\
\text { discontinued use of pain medications. }\end{array}$ \\
\hline Goyal, $2010^{51}$ & Case report & 1 & $\begin{array}{l}\text { Lung } \\
\text { adenocarcinoma }\end{array}$ & Post-thoracotomy scar pain & & $\begin{array}{l}80-90 \% \text { pain relief at } 6 \text { months post- } \\
\text { implant }\end{array}$ \\
\hline $\begin{array}{l}\text { Viswanathan, } \\
2010^{53}\end{array}$ & Case series & 4 & $\begin{array}{l}\text { Hemangiomatosis, } \\
\text { rhabdosarcoma, } \\
\text { spindle cell } \\
\text { carcinoma, } \\
\text { chondrosarcoma }\end{array}$ & $\begin{array}{l}\text { Post-surgical amputation phantom } \\
\text { limb pain }\end{array}$ & & $\begin{array}{l}\text { All four patients experienced at least } \\
80 \% \text { pain relief; one pt. developed an } \\
\text { allergic reaction to the IPG, and } \\
\text { another developed a surgical site } \\
\text { infection following routine exchange } \\
\text { of IPG }\end{array}$ \\
\hline $\begin{array}{l}\text { Yakovlev, } \\
2012^{38}\end{array}$ & $\begin{array}{l}\text { Retrospective } \\
\text { Review }\end{array}$ & 15 & $\begin{array}{l}\text { Metastatic colon } \\
\text { cancer, anal cancer, } \\
\text { and angiosarcoma } \\
\text { of the sacrum }\end{array}$ & $\begin{array}{l}\text { No pain prior to cancer treatments, } \\
\text { so presumed related to treatment. }\end{array}$ & $\begin{array}{l}\text { Traditional } \\
\text { SCS }\end{array}$ & $\begin{array}{l}\text { At } 12 \text { months post-implant, all } \\
\text { patients had }>50 \% \text { VAS pain } \\
\text { reduction. Thirteen patients } \\
\text { decreased or discontinued pain } \\
\text { medications. }\end{array}$ \\
\hline $\begin{array}{l}\text { Wininger, } \\
2012^{52}\end{array}$ & Case report & 1 & $\begin{array}{l}\text { Non-small cell lung } \\
\text { carcinoma }\end{array}$ & $\begin{array}{l}\text { Post-thoracotomy neuralgia at T6 } \\
\text { and T7 dermatomes }\end{array}$ & & $\begin{array}{l}>75 \% \text { pain relief, improvement in } \\
\text { quality of life, improved functional } \\
\text { ability with arm movement, improved } \\
\text { sleep pattern at } 24 \text { months post- } \\
\text { implant }\end{array}$ \\
\hline
\end{tabular}

(Continued) 
Table 2 (Continued).

\begin{tabular}{|l|l|l|l|l|l|l|}
\hline $\begin{array}{l}\text { Author, } \\
\text { Year }\end{array}$ & Study Type & $\begin{array}{l}\text { No. of } \\
\text { Patients }\end{array}$ & Cancer Type & Pain Etiology & $\begin{array}{l}\text { Stimulation } \\
\text { Mode }\end{array}$ & Results \\
\hline Elahi, 201349 & Case report & 1 & Prostate cancer & $\begin{array}{l}\text { Pudendal neuropathy post-radiation } \\
\text { therapy }\end{array}$ & $\begin{array}{l}\text { NRS decreased to I from pre-trial } \\
\text { score of } 8 \text { (87\% pain relief), as well as } \\
100 \% \text { overall satisfaction at } 10-\text { month } \\
\text { post-implant }\end{array}$ \\
\hline $\begin{array}{l}\text { Abd-Elsayed, } \\
2016^{47}\end{array}$ & Case Series & $\begin{array}{l}\text { I (2 non- } \\
\text { cancer } \\
\text { patients } \\
\text { excluded })\end{array}$ & Breast Cancer & $\begin{array}{l}\text { Chemotherapy-induced painful } \\
\text { neuropathy }\end{array}$ & $\begin{array}{l}95 \% \text { pain relief at I week trial that } \\
\text { persisted 3 months post-implant }\end{array}$ \\
\hline
\end{tabular}

Abbreviations: Pt, patient; OME, oral morphine equivalent; NRS, numerical rating scale; IPG, implantable pulse generator; VAS, visual analog scale; ODI, Oswestry disability index; SF-MPQ, McGill Pain Questionnaire short-form; BDI, Beck Depression Inventory.

spinal meningioma removal. ${ }^{54}$ Patients undergoing surgery for malignancy may not necessarily be at higher risk for chronic pain, but certainly the complexity of surgery and possibly related comorbidities can result in pain syndromes not commonly seen in patients without a history of cancer.

As an indicated therapy for intractable neuropathic pain of the trunk and/or extremities, patients with cancer treatment-associated pain may be candidates for this type of advanced intervention. Particularly in patients who have undergone successful treatment and have normal life expectancy, non-opioid-based interventions such as neuromodulation are attractive options for improving pain and quality of life in patients experiencing chronic pain following cancer treatment. An updated systematic review of spinal cord stimulation for cancer-associated pain did not find sufficient high-quality evidence to recommend neuromodulation as a superior therapy to pharmacologic agents for treating cancer-related pain. ${ }^{41}$ To the best of our knowledge with a librarian-assisted literature search strategy, the authors did not find a single randomized controlled trial assessing the safety or efficacy of neuromodulation for cancer-associated pain, and our current review did not identify any new trials since this review was published in 2015. While we are optimistic about the use of neuromodulation for cancertreatment-related pain, more evidence is needed to assess the safety and efficacy of neuromodulation in this patient population.

\section{Precautions in Cancer Pain Patients Receiving SCS}

Given the consequences of cancer and cancer treatments on hemostasis of the body, precautions should be undertaken to avoid complications. Specifically, immunosuppression, coagulopathy, and the potential for poor wound healing need to be considered. We will consider each of these areas below.

\section{Immunosuppression}

Cancer immunosuppression can occur from cancermediated factors or from treatment-related effects. Cancer cells create an immunosuppressive network secondary to secretion of tumor-derived soluble factors (TDSFs), such as interleukin-10 (IL-10), transforming growth factor-beta (TGF-beta), and vascular endothelial growth factor (VEGF). ${ }^{55}$ These factors promote creation of immature myeloid cells and T cells, which are attracted to the cancer site. Upon arrival, they are biochemically modulated causing inhibition of dendritic cell maturation and functional inhibition of T-cells and NK-cells. ${ }^{56}$ Because of these changes, there is impaired phagocytosis and clearance of apoptotic cells, which induces anti-DNA antibodies and a condition resembling autoimmune disease. ${ }^{55}$ Altogether, these immunosuppressive changes increase the risk of postoperative infections, in addition to tumor progression.

When considering infection risk based on cancer type, hematologic malignancies are associated with an increased risk overall. Due to functional asplenia, hypogammaglobulinemia, and impaired B-cell immunity, these patients have an increased risk of encapsulated bacterial infections. ${ }^{57}$ They are also at risk of mycobacterial and viral infections given defective T-cell immunity. If myelodysplastic syndrome develops, this places the patient at increased risk of bacterial, viral, and fungal infections related to neutropenia. ${ }^{57}$

Cancer treatments can also place patients at an increased risk of infection. Radiation has been shown to increase production of TGF-beta on a per cell basis. ${ }^{56}$ As 
mentioned earlier, elevated TGF-beta causes immunosuppression. Chemotherapy causes neutropenia (absolute neutrophil count $[\mathrm{ANC}]<500$ cells $/ \mathrm{mm}^{3}$ ) and decreased granulocytes may encourage bacterial and fungal infections. ${ }^{57,58}$ Nucleoside analogs cause T-cell depletion and increase risk of bacterial and viral infections. Alemtuzumab causes a broad defect in host immune defenses, which leads to risk of bacterial, viral, and fungal infections. Rituximab decreases B-cell immunity, which poses a risk of bacterial infections. Other drugs inhibit cytokine signaling (ex. Infliximab), which increases the risk of bacterial, viral, and fungal infections. Lastly, calcineurin inhibitors cause defective T-cell immunity that puts the patient at risk of viral infections. ${ }^{57}$ We advise close inspection of the patient's chemotherapeutic drug regimen to properly determine immunologic risks.

Autologous hematopoietic stem cell transplantation causes weeks of neutropenia, which is followed by weeks or months of defective T-cell immunity. This may increase the risk of bacterial infections in the short-term and viral infections over time. Allogeneic transplantation is even more complex.

Depending on a number of factors, particularly those related to the transplant match and graft-versus-host-disease prophylaxis, these patients are at an increased risk of infection for months afterwards from a variety of organisms. $^{57,58}$

\section{Coagulopathy}

Thrombotic and bleeding complications are not uncommon in cancer and it involves a complex interplay of underlying mechanisms. Given the prothrombotic properties of tumor cells and microvascular dysfunction, venous thromboembolism occurs in approximately $20 \%$ of patients and is the second most common cause of death in this patient population. ${ }^{59}$ Due to increased clotting, there is a consumptive coagulopathy present that leads to a disorder of coagulation, particularly involving platelets and the complement system. Similar to disseminated intravascular coagulation, but less severe given its chronic and gradual progression, these patients are at risk of significant bleeding following minor skin breaches, including surgical incisions. ${ }^{60}$

\section{Compromised Wound Healing}

Cancer and its treatments cause significant physiologic changes. Given the wide range of treatment options, including surgery, radiation, and chemotherapeutic agents, wound healing becomes critically important in the continuum of cancer care. Wound healing involves a myriad of interweaving processes, and any cancer or treatment-related disruption in this progression can affect the body's healing abilities.

Nutrition plays an important role in cancer care and the healing process. It is well documented that positive nutritional balance promotes optimal wound healing, and physicians must consider this when considering surgical intervention. ${ }^{61}$ Malnourished patients have an increased susceptibility to surgical site complications, including infection and delayed wound healing. Nutritional supplementation, specifically fluids, vitamins (especially Vitamins C and A), protein, fat, carbohydrates, and overall calories, should be considered in cancer patients to minimize or reverse the negative consequences of malnutrition. In order to provide this, enteral or parenteral routes may need to be employed. Prealbumin and albumin levels should be considered in all patients preoperatively and in those individuals presenting with nonhealing wounds. $^{61}$

Treatment-related effects on wound healing must also be considered. Radiotherapy causes ionization and subsequent cellular damage to vital structures. High-turnover cells are more susceptible to this damage, including epithelial cells, and this may lead to delayed wound healing at sites of radiation. $^{61-63}$ Chemotherapy is a common and essential treatment in cancer care. Similar to radiotherapy, chemotherapeutic agents preferentially target rapidly dividing cells, and this includes tissues involved with incisional healing. ${ }^{61,64}$ VEGF inhibitors are particularly detrimental to wound healing given the known effects on angiogenesis. ${ }^{65,66}$ Corticosteroids are often employed for patients with cancer to assist with pain control; however, early administration following surgery has been shown to have negative consequences on wound tensile strength. ${ }^{61}$ This is caused by the expected anti-inflammatory response of corticosteroids, which suppresses the progression of wound healing.

\section{Future Directions}

Cancer-related pain represents an important public health problem in terms of the number of patients afflicted and health care costs. ${ }^{67}$ Most patients with cancer-related pain are treated with opioid and non-opioid medications as the mainstays of therapy, and yet many medically treated patients continue to report ongoing pain and decreased quality of life. ${ }^{68}$ Additionally, adverse effects from painrelated medications represent a considerable challenge for clinicians and patients. Central nervous system and 
gastrointestinal side effects, in particular, are common and often lead to significant patient morbidity and impaired quality of life. ${ }^{69-71}$

SCS obtained US Food and Drug Administration approval in 1989, for the treatment of intractable pain of the trunk and/or limbs. ${ }^{8}$ Since then, the device hardware, technology, and software contained within the impulse generators have drastically improved and along with that, patient outcomes have improved as well. ${ }^{72} \mathrm{SCS}$ has been demonstrated in several RCTs totaling over 1000 patients, to provide improved pain control when compared to medical therapy in many challenging chronic neuropathic pain conditions including chronic spine pain persisting after surgery, painful diabetic neuropathy, complex regional pain syndrome, and pain in the setting of peripheral vascular disease. ${ }^{12}$ The therapy appears to provide effective pain control across a variety of neuropathic pain conditions and pain-inducing mechanisms. There is an important need to study SCS in cancer-related pain conditions, particularly when considering the shortcomings of the current published literature in this area (including retrospective study designs, small patient numbers, and no inclusion of neurostimulation technological advancements). However, based upon the experience with SCS in the non-cancer pain population and on small series and case reports in cancer pain, it seems highly likely that SCS can be a useful and effective therapy in many of the challenging cancer-related neuropathic pain syndromes such as post radiation neuropathic pain, chemotherapyinduced peripheral neuropathies, and post-surgical pain syndromes. ${ }^{4,52,73}$

This is especially important going forward: as cancer survival rates continue to increase, patients who are afflicted with these debilitating pain conditions may endure long periods of pain and suffering if the underlying pain problem is not optimally treated. ${ }^{74}$ Clinical trials comparing conventional medical therapy to SCS for the aforementioned pain syndromes are needed and would have the highest impact for the greatest number of patients. Additionally, assessment of patient-related characteristics that predict successful therapeutic response from SCS should also be evaluated with a focus on demographic predictor variables (ie, age, gender), type and stage of cancer, type of pain (ie, somatic, visceral, neuropathic), pre-procedural opioid use, and other comorbidities (ie, psychiatric disorder). Until then, patients with intractable pain despite maximal medical therapy should be referred to an interventional pain specialist to assess for candidacy of advanced interventional treatment options such as SCS.
Lastly, specific timing for safe SCS use in the setting of ongoing cancer-related treatment requires study. As discussed above, these situations are complex and many aspects of patient care are affected. Currently, the authors would recommend following institutional guidelines and having clear communication with the entire care team to ensure optimal patient outcomes and minimize complications. Similarly, the need for future cancer surveillance imaging requires consideration as this may influence device selection. ${ }^{75}$

\section{Conclusion}

Cancer and cancer treatment-related chronic pain affect a significant number of oncologic patients and this is likely to increase in the coming years as survival is enhanced. While these symptoms have traditionally been managed with medications, injections, and neuraxial therapies, there is low-level evidence that SCS and DRG stimulation should be considered as an additional therapeutic option. When considering evidence from non-cancer pain studies, there is Level 1 evidence to support the use of SCS and DRG stimulation in chronic neuropathic pain states. Given the similarities in pain quality found in many cancer patients, it is crucial that we research and explore this therapeutic option in the cancer pain population.

\section{Acknowledgements}

The authors thank Julie M. Taylor MLS from Mayo Library System, Mayo Clinic, Rochester, MN for her significant contribution with the literature search and abstract procurement.

\section{Funding}

There is no funding to report.

\section{Disclosure}

TPP, CLH, RSD, and TJL report no conflicts. JMH is a consultant for Abbott and Nevro, a member of an advisory board for Boston Scientific, and reports personal fees from Nevro Corp, outside the submitted work. The authors report no other conflicts of interest for this work.

\section{References}

1. Gralow I. Cancer pain: an update of pharmacological approaches in pain therapy. Curr Opin Anaesthesiol. 2002;15(5):555-561. doi:10.1097/00001503-200210000-00014

2. Bruera E. Cancer pain. JAMA. 2003;290(18):2476-2479. doi:10.1001/ jama.290.18.2476

3. Running A, Turnbeaugh E. Oncology pain and complementary therapy. Clin J Oncol Nurs. 2011;15(4):374-379. doi:10.1188/11. CJON.374-379 
4. Yakovlev AE, Ellias Y. Spinal cord stimulation as a treatment option for intractable neuropathic cancer pain. Clin Med Res. 2008;6(3-4):103-106. doi:10.3121/cmr.2008.813

5. Berger A, Dukes E, Mercadante S, Oster G. Use of antiepileptics and tricyclic antidepressants in cancer patients with neuropathic pain. Eur $J$ Cancer Care (Engl). 2006;15(2):138-145.

6. Slavik E, Ivanović S. Cancer pain (neurosurgical management). Acta Chir Iugosl. 2004;51(4):15-23.

7. Linderoth B, Foreman RD. Conventional and Novel Spinal Stimulation Algorithms: hypothetical Mechanisms of Action and Comments on Outcomes. Neuromodulation. 2017;20(6):525-533.

8. Lamer TJ, Deer TR, Hayek SM. Advanced Innovations for Pain. Mayo Clinic Proce. 2016;91:246-258.

9. Hagedorn JM, Demian PS, Scarfo KA, Engle AM, Deer TR. Proclaim DRG Neurostimulator System for the management of chronic, intractable pain. Pain Manag. 2020;10(4):225-233.

10. Deer TR, Grider JS, Lamer TJ, et al. A Systematic Literature Review of Spine Neurostimulation Therapies for the Treatment of Pain. Pain Med. 2020;21(7):1421-1432. doi:10.1093/pm/pnz353

11. Klomp HM, Steyerberg EW, Habbema JD, van Urk H. group Es. What is the evidence on efficacy of spinal cord stimulation in (subgroups of) patients with critical limb ischemia? Ann Vasc Surg. 2009;23(3):355-363. doi:10.1016/j.avsg.2008.08.016

12. Lamer TJ, Moeschler SM, Gazelka HM, Hooten WM, Bendel MA, Murad MH. Spinal Stimulation for the Treatment of Intractable Spine and Limb Pain: A Systematic Review of RCTs and Meta-Analysis. Mayo Clinic Proceedings. 2019;94(8):1475-1487. doi:10.1016/j. mayocp.2018.12.037

13. He Q-H, Liu Q-L, Li Z, Li K-Z, Xie Y-G. Impact of epidural analgesia on quality of life and pain in advanced cancer patients. Pain Management Nursing. 2015;16(3):307-313. doi:10.1016/j. pmn.2014.08.003

14. Ovayolu N, Ovayolu Ö, Serçe S, Tuna D, Pirbudak Çöçelli L, Sevinç A. Pain and quality of life in Turkish cancer patients. Nurs Health Sci. 2013;15(4):437-443. doi:10.1111/nhs.12047

15. Deng D, Fu L, Zhao YX, et al. The relationship between cancer pain and quality of life in patients newly admitted to wuhan hospice center of China. Am J Hosp Palliat Care. 2012;29(1):53-59. doi:10.1177/ 1049909111418636

16. O'Mahony S, Goulet J, Kornblith A, et al. Desire for hastened death, cancer pain and depression: report of a longitudinal observational study. J Pain Symptom Manage. 2005;29(5):446-457. doi:10.1016/j. jpainsymman.2004.08.010

17. Harrington CB, Hansen JA, Moskowitz M, Todd BL, Feuerstein M. It's Not over When it's Over: long-Term Symptoms in Cancer Survivors-A Systematic Review. Int J Psychiatry Med. 2010;40 (2):163-181. doi:10.2190/PM.40.2.c

18. Zylla D, Kuskowski MA, Gupta K, Gupta P. Association of opioid requirement and cancer pain with survival in advanced non-small cell lung cancer. $B r \quad J$ Anaesth. 2014;113(Suppl 1):i109-i116. doi:10.1093/bja/aeu351

19. Halabi S, Lin C-Y, Kelly WK, et al. Updated prognostic model for predicting overall survival in first-line chemotherapy for patients with metastatic castration-resistant prostate cancer. J Clin Oncol. 2014;32 (7):671-677. doi:10.1200/JCO.2013.52.3696

20. Boland JW, Ziegler L, Boland EG, McDermid K, Bennett MI. Is regular systemic opioid analgesia associated with shorter survival in adult patients with cancer? A systematic literature review. Pain. 2015;156(11):2152-2163. doi:10.1097/j.pain.0000000000000306

21. Pollard EM, Lamer TJ, Moeschler SM, et al. $<\mathrm{p}>$ The effect of spinal cord stimulation on pain medication reduction in intractable spine and limb pain: a systematic review of randomized controlled trials and meta-analysis. J Pain Res. 2019;12:1311-1324. doi:10.2147/JPR. S186662

22. Portenoy RK. Treatment of cancer pain. Lancet. 2011;377 (9784):2236-2247. doi:10.1016/S0140-6736(11)60236-5
23. Falk S, Dickenson AH. Pain and nociception: mechanisms of cancer-induced bone pain. J Clin Oncol. 2014;32(16):1647-1654. doi:10.1200/JCO.2013.51.7219

24. Mantyh PW. Bone cancer pain: from mechanism to therapy. Curr Opin Support Palliat Care. 2014;8(2):83-90. doi:10.1097/ SPC.0000000000000048

25. Cheville AL, Murthy N, Basford JR, et al. Imaging and Clinical Characteristics Predict Near-Term Disablement From Bone Metastases: implications for Rehabilitation. Arch Phys Med Rehabil. 2016;97(1):53-60. doi:10.1016/j.apmr.2015.09.011

26. Mirpuri RG, Chang E, Brammeier J, et al. Spinal cord stimulation for treatment of the pain associated with hereditary multiple osteochondromas. J Pain Res. 2015;8:557-560. doi:10.2147/JPR.S86790

27. Hutson N, Hung JC, Puttanniah V, et al. Interventional Pain Management for Sacroiliac Tumors in the Oncologic Population: A Case Series and Paradigm Approach. Pain Med. 2017;18(5):959-968.

28. Sikandar S, Dickenson AH. Visceral pain: the ins and outs, the ups and downs. Curr Opin Support Palliat Care. 2012;6(1):17-26. doi:10.1097/SPC.0b013e32834f6ec9

29. Flagg A, McGreevy K, Williams K. Spinal cord stimulation in the treatment of cancer-related pain: "back to the origins". Curr Pain Headache Rep. 2012;16(4):343-349. doi:10.1007/s11916-012-0276-9

30. So M, Bansal N, Piracha MM. Neuromodulation and Pancreatic Cancer Pain. J Palliat Med. 2018;21(8):1064-1066. doi:10.1089/jpm.2018.0109

31. Guttman OT, Hammer A, Korsharskyy B. Spinal cord stimulation as a novel approach to the treatment of refractory neuropathic mediastinal pain. Pain Pract. 2009;9(4):308-311. doi:10.1111/j.15332500.2009.00288.x

32. Shiraishi M, Hanzawa K, Motoyama Y. Anesthetic management for pheochromocytoma resection using spinal cord stimulation and intravenous nicardipine-a case report. Acta Anaesthesiol Sin. 1999;37 (2):83-87.

33. Shealy CN, Mortimer JT, Reswick JB. Electrical Inhibition of Pain by Stimulation of the Dorsal Columns: preliminary Clinical Report. Anesth Analg. 1967;46(4):489-491. doi:10.1213/00000539-196707000-00025

34. Cata JP, Cordella JV, Burton AW, et al. Spinal cord stimulation relieves chemotherapy-induced pain: a clinical case report. J Pain Symptom Manage. 2004;27(1):72-78. doi:10.1016/j.jpainsymman.2003.05.007

35. Eisenberg E, Brecker C. Lumbar spinal cord stimulation for cervical-originated central pain: a case report. Pain. 2002;100 (3):299-301. doi:10.1016/S0304-3959(02)00267-1

36. Meglio M, Cioni B, Rossi GF. Spinal cord stimulation in management of chronic pain: a 9-year experience. J Neurosurg. 1989;70 (4):519-524. doi:10.3171/jns.1989.70.4.0519

37. Shimoji K, Hokari T, Kano T, et al. Management of intractable pain with percutaneous epidural spinal cord stimulation: differences in pain-relieving effects among diseases and sites of pain. Anesth Analg. 1993;77(1):110-116. doi:10.1213/00000539-199307000-00022

38. Yakovlev AE, Resch BE. Spinal cord stimulation for cancer-related low back pain. Am J Hosp Palliat Care. 2012;29(2):93-97. doi:10.1177/1049909111410414

39. Yakovlev AE, Resch BE, Karasev SA. Treatment of cancer-related chest wall pain using spinal cord stimulation. Am J Hosp Palliat Care. 2010;27(8):552-556. doi:10.1177/1049909110373240

40. Dombovy-Johnson ML, Hunt CL, Morrow MM, Lamer TJ, Pittelkow TP. Current evidence lacking to guide clinical practice for spinal cord stimulation in the treatment of neuropathic pain in spinal cord injury: a review of the literature and a proposal for future study. Pain Pract. 2020;20(3):325-335. doi:10.1111/papr.12855

41. Peng L, et al. Spinal cord stimulation for cancer-related pain in adults. Cochrane Database Syst Rev. 2015;2015(6):Cd009389.

42. Hagedorn JM, Layno-Moses A, Sanders DT, et al. Overview of HF10 spinal cord stimulation for the trea ${ }^{\mathrm{TM}}$ ent of chronic pain and an introduction to the Senza Omnia ${ }^{\mathrm{TM}}$ system. Pain Management. 2010;10(6):367-376. doi:10.2217/pmt-2020-0047 
43. Hagedorn JM, Engle AM, Ghosh P, Deer TR. Device profile of the Proclaim XR neurostimulation system for the treatment of chronic pain: an overview of its safety and efficacy. Expert Rev Med Devices. 2020;17(6):499-505. doi:10.1080/17434440.2020.1773258

44. Neufeld NJ, Elnahal SM, Alvarez RH. Cancer pain: a review of epidemiology, clinical quality and value impact. Future Oncol. 2017;13(9):833-841. doi:10.2217/fon-2016-0423

45. Nijs J, Leysen L, Adriaenssens N, et al. Pain following cancer treatment: guidelines for the clinical classification of predominant neuropathic, nociceptive and central sensitization pain. Acta Oncol. 2016;55(6):659-663. doi:10.3109/0284186X.2016.1167958

46. Portenoy RK, Ahmed E. Cancer Pain Syndromes. Hematol Oncol Clin North Am. 2018;32(3):371-386.

47. Abd-Elsayed A, Schiavoni N, Sachdeva H. Efficacy of spinal cord stimulators in treating peripheral neuropathy: a case series. $J$ Clin Anesth. 2016;28:74-77.

48. Ting JC, Fukshansky M, Burton AW. Treatment of refractory ischemic pain from chemotherapy-induced Raynaud's syndrome with spinal cord stimulation. Pain Pract. 2007;7(2):143-146.

49. Elahi F, Callahan D, Greenlee J, Dann TL. Pudendal entrapment neuropathy: a rare complication of pelvic radiation therapy. Pain Physician. 2013;16(6):E793-7.

50. Hamid B, Haider N. Spinal cord stimulator relieves neuropathic pain in a patient with radiation-induced transverse myelitis. Pain Pract. 2007;7(4):345-347.

51. Goyal GN, Gupta D, Jain R, Kumar S, Mishra S, Bhatnagar S. Peripheral nerve field stimulation for intractable post-thoracotomy scar pain not relieved by conventional treatment. Pain Pract. 2010;10(4):366-369.

52. Wininger KL, Bester ML, Deshpande KK. Spinal cord stimulation to treat postthoracotomy neuralgia: non-small-cell lung cancer: a case report. Pain Manag Nurs. 2012;13(1):52-59.

53. Viswanathan A, Phan PC, Burton AW. Use of spinal cord stimulation in the treatment of phantom limb pain: case series and review of the literature. Pain Pract. 2010;10(5):479-484.

54. Lee MG, Choi SS, Lee MK, Kong MH, Lee IO, Oh HR. Thoracic spinal cord stimulation for neuropathic pain after spinal meningioma removal: a case report. Clin J Pain. 2009;25(2):167-169.

55. Kim R, Emi M, Tanabe K. Cancer immunosuppression and autoimmune disease: beyond immunosuppressive networks for tumour immunity. Immunology. 2006;119(2):254-264.

56. WH RH C, Herberman RB. Mechanisms of Immunosuppression. In: Kufe DWPR, Weichselbaum RR, editors. Holland-Frei Cancer Medicine. 6th ed ed. Hamilton (ON): BC Decker; 2003.

57. TN PM P, Cuéllar-Rodríguez J, Gea-Banacloche JC. Infections in the Cancer Patient. In: DeVita VTLT, Rosenberg SA, editors. Devita, Hellman, and Rosenberg's Cancer: Principles \& Practice of Oncology. Lippincott Williams \& Wilkins; 2015.

58. Jolissaint JS, Harary M, Saadat LV, et al. Timing and Outcomes of Abdominal Surgery in Neutropenic Patients. J Gastrointest Surg. 2019;23(4):643-650.
59. Dammacco F, Vacca A, Procaccio P, Ria R, Marech I, Racanelli V. Cancer-related coagulopathy (Trousseau's syndrome): review of the literature and experience of a single center of internal medicine. Clin Exp Med. 2013;13(2):85-97.

60. Levi M, Sivapalaratnam S. Disseminated intravascular coagulation: an update on pathogenesis and diagnosis. Expert Rev Hematol. 2018;11(8):663-672.

61. Payne WG, Naidu DK, Wheeler CK, et al. Wound healing in patients with cancer. Eplasty. 2008;8:e9.

62. Mendelsohn FA, Divino CM, Reis ED, Kerstein MD. Wound care after radiation therapy. Adv Skin Wound Care. 2002;15(5):216-224.

63. Hopewell JW. The skin: its structure and response to ionizing radiation. Int J Radiat Biol. 1990;57(4):751-773.

64. Cohen SC, Gabelnick HL, Johnson RK, Goldin A. Effects of antineoplastic agents on wound healing in mice. Surgery. 1975;78(2):238-244.

65. Bates DO, Jones RO. The role of vascular endothelial growth factor in wound healing. Int J Low Extrem Wounds. 2003;2(2):107-120.

66. Scappaticci FA, Fehrenbacher L, Cartwright T, et al. Surgical wound healing complications in metastatic colorectal cancer patients treated with bevacizumab. J Surg Oncol. 2005;91(3):173-180.

67. van den Beuken-van Everdingen MH, Hochstenbach LM, Joosten EA, Tjan-Heijnen VC, Janssen DJ. Update on prevalence of pain in patients with cancer: systematic review and meta-analysis. J Pain Symptom Manage. 2016;51:1070-1090.

68. WHO guidelines for the pharmacological and radiotherapeutic management of cancer pain in adults and adolescents. Geneva: World Health Organization. Licence: CC BY-NC-SA 3. IGO. 2018.

69. Smith TJ, Coyne PJ, Staats PS, et al. An implantable drug delivery system (IDDS) for refractory cancer pain provides sustained pain control, less drug-related toxicity, and possibly better survival compared with comprehensive medical management (CMM). Ann Oncol. 2005;16(5):825-833.

70. Wiffen PJ, Wee B, Derry S, Bell RF, Moore RA. Opioids for cancer pain - an overview of Cochrane reviews. Cochrane Database Syst Rev. 2017;7:7.

71. Guan J, Tanaka S, Kawakami K. Anticonvulsants or antidepressants in combination pharmacotherapy for treatment of neuropathic pain in cancer patients: a systematic review and meta-analysis. Clin J Pain. 2016;32:719-725.

72. Deer TR, Hagedorn JM, Jameson JB, Mekhail N. A new horizon in neuromodulation. Pain Med. 2020.

73. Walsh L, Guha D, Purdie TG, et al. Spinal cord stimulators and radiotherapy: first case report and practice guidelines. Radiat Oncol. 2011;6:143.

74. Morgalla MH. Dorsal root ganglion stimulation for the treatment of persistent post-mastectomy pain: case report. Neuromodulation. 2019;22(1):117-118.

75. Sayed D, Chakravarthy K, Amirdelfan K, et al. A Comprehensive Practice Guideline for Magnetic Resonance Imaging Compatibility in Implanted Neuromodulation Devices. Neuromodulation. 2020;23(7):893-911.
Journal of Pain Research

\section{Publish your work in this journal}

The Journal of Pain Research is an international, peer reviewed, open access, online journal that welcomes laboratory and clinical findings in the fields of pain research and the prevention and management of pain. Original research, reviews, symposium reports, hypothesis formation and commentaries are all considered for publication. The manuscript

Submit your manuscript here: https://www.dovepress.com/journal-of-pain-research-journal management system is completely online and includes a very quick and fair peer-review system, which is all easy to use. Visit http:// www.dovepress.com/testimonials.php to read real quotes from published authors. 